\title{
Chapter 10 \\ Governmentality: The Notion of Progress in the Brazilian Political Educational \\ Discourse
}

\author{
Márcia Aparecida Amador Mascia
}

\subsection{Introduction}

Taking into account that the discourse of progress is at the basis of our current educational policy, this chapter aims at exploring the foundations of this concept in education using as tools the discursive framework in the convergence with Foucault's studies of power and governmentality. For the discussion of progress and curricula, this study relies on Popkewitz. The questions that mobilize the discussion refers to the rules upon which the discourse of progress in education is constructed and, also, how these rules are linguistically materialized in a local example.

The materials that are analyzed are excerpts of documents of Brazilian Curriculum Discourse, focusing on curricula reforms that took place in the 1980 and 1990. My great argument here is that this discourse operates under dichotomies of progress/ regression, success/failure, and inclusion/exclusion, naturalizing them. I wish to demonstrate that these dichotomies should not be accepted as naturalized but should be considered a social construction and part of the effects of power in the education system of reasoning.

This chapter is intended to be neither the origin nor the last word about the relations of progress in education, instead it should be viewed as a continuity and/or discontinuity in the discourse on education. The intention is to deconstruct some concepts often related to education: Liberalism, progress, power, and truth. This investigation does not discuss what includes or excludes, but how the discourses create a system of reasoning of inclusion and exclusion in education.

\footnotetext{
A version of this chapter was first published in the volume: Mascia, Márcia A. A. (2009). Inclusion or Exclusion? An Analysis of the Brazilian Curriculum Discourse of the 1980s and the 1990s. Culture and Emerging Educational Challenges: A Dialogue with Brazil/Latin America. Michalis Kontopodis (Ed.). Lehmanns Media.
}

M. A. A. Mascia $(\bowtie)$

Universidade São Francisco, Itatiba, Sao Paulo, Brazil 
My experience as a teacher in Brazil has been that there is a constant concern about the issues of exclusion and failure in schooling, in a sense of qualifying and disqualifying students, teachers, approaches, and curricula proposals. For decades, we have watched movements of democratization and redemocratization of education, with countless curricula reforms. But we have noticed that there was something wrong: the reforms were implemented, but the school remained the same. "What could be the matter?" I asked. My discomfort as a teacher and researcher made me start thinking that we had probably been asking the wrong questions. Instead of pursuing what works or does not work in education, as a linguist and discourse analyst, I realized that we should try to look at education discourses and examine the systems of reasons that enable us to think education in a dichotomous way, of inclusion and exclusion. The great argument of this chapter is that this system is a historically constructed discourse.

All research involves theoretical background that points not only to the analysis but also to the data. When we look for and at the data, we cross into theoretical considerations that head our process of selecting, viewing, and interpreting.

In the next section, we pursue the main concepts in which we will inscribe our arguments.

\subsection{Theoretical Background}

The theoretical background lies on post critical thinkers. We are presenting in this part the notion of progress; object and subject from the discursive point of view; power and governmentality for Foucault.

\subsubsection{Liberalism and Progress as Discourses}

One of the greatest challenges of the modern State is to develop strategies for social inclusion; yet as inclusion strategies are sought, patterns of exclusion remain prominent in social policy and education. These mechanisms of inclusion are embedded in the Liberal thought which underlies the Enlightenment claim of equality of men. Enlightenment believed that systematic knowledge was the motor by which "reason" could direct social action and guarantee a good future in society.

According to Mehta (1997), although Liberalism claims, from the theoretical point of view, a politics of inclusion, in practice, it has actually been exclusionary. This occurs because:

Liberal theoretical claims typically tend to be transhistorical, transcultural, and most certainly transracial. (...) What is meant by this is that the universal claims can be made because they derive from certain characteristics that are common to all human beings. (op. cit., p. 63)

But the exclusionary bases of liberalism, I believe, derive from its theoretical core. (...) It is not because the ideals are theoretically disingenuous or concretely impractical, but 
rather because behind the capacities ascribed to all human beings there exists a thicker set of social credentials that constitute the real bases of political inclusion. (op. cit., p. 61)

In this sense, what Liberalism forgets is that men are social beings and that they are embodied in power relations.

Taking into account the notion of progress in Liberalism, it can be said that liberal theory assumes scientific knowledge and, in liberal thought, progress is obtained through managing social change. Popkewitz reinforces this idea, postulating for the American educational system that "in contemporary school reforms, these fundamental assumptions are deeply embedded as part of the doxa. Dominant and liberal educational reform discourses have tended to organize change as logical and sequential" (Popkewitz 1997a: 291).

According to Popkewitz, it is possible to postulate two different ideological forms in contemporary social and educational theory: the critical and the liberal traditions, both of which relate to the nineteenth century view of Enlightenment. In terms of Popkewitz (id., ibid.):

For critical and liberal theorists, change was premised on identifying the subjects who gave direction to change, either by locating the origins of repressive elements that prevented progress or the groups that would bring about a redemptive world.

If we think of Brazilian schooling models, we can say that critical and liberal traditions provide foundational assumptions of progress.

We will now pursue some fundamental concepts that will help understand history as a theoretical activity. In this work, when we talk about history, we are talking about discourses, as Foucault defined and was adopted by the French Discourse Analysis:

(...) a body of anonymous, historical rules, always determined in the time and space that have defined a given period, and for a given social, economic, or linguistic area, the conditions of operation of the enunciative function. (Foucault 1972: 117)

Thus, discursive formations are constituted by discursive practices that determine the objects, the enunciative modalities of the subject, the concepts, and the thematic choices. Discourses could be viewed as discontinuity practices that intersect with each other, juxtapose one another, but also sometimes ignore or exclude each other.

In light of the above, we inscribe the study of Liberalism in education in a study that should contemplate the discourses, that is, the historically constructed principles of classification and ordering of the world. Those who inscribe their researches in the post-modern studies broadly adopt this concept of history as discourses. For post-modern studies, the object does not pre-exist; it is actually constructed according to certain social and historical rules, the rules of discursive formations. These rules dictate what and/or how we are to interpret the world, transforming some things into data to the detriment of others.

But, apart from this interpretation of history as discursive practices adopted by post-modernity, there is another interpretation that we could label as traditional history upon which the Liberalism is based. Popkewitz (1997b: 136-139) focuses on these two systems and the differences between them. He makes a distinction 
between what he calls the historicism or philosophy of consciousness and the "linguistic turn." The former, which has dominated social studies, sees events as "real" and performed by "actors"; the latter, which was adopted by genealogical studies and social epistemology, focuses on language as a constitutive element in the construction of social life and "identity." The difference between them most interesting here is their concepts of progress. For the historicist view, progress is an a priori concept and is conceived as a movement from evil to good, applied to the social conditions of life. The task of social science in this perspective is to detect bad conditions, analyze them, and propose ways of improvement. However, for the "linguistic turn," which we are adopting in this work, "progress" is seen as change, and it is constitutive to social practices and does not pursue an ideal world. The "linguistic turn" (Usher and Edwards 1994) focuses on the language, assuming that our relation with the world is crossed by language, that is, the rules that tell what, when, and in which way we should say, act, and see the world and ourselves.

The way we see change is as a social constructed image intermediated by language. The images of liberalist change in education through the improvement of curricula involve not only education but also the politics of knowledge of the world, that is, our relation with language.

In the same line of thinking, Bakhtin (1973) works with the meaning of the sign crossed by the language:

Meaning is the expression of a semiotic relationship between a particular piece of reality and another kind of reality that it stands for, represents, or depicts. Meaning is a function of a sign and therefore inconceivable outside the sign as some particular, independently existing thing. (op. cit., p. 28)

In short, anything and everything occurring within the organism can become the material of experience, since everything can acquire semiotic significance, can become expressive. But all the same, it is the word that constitutes the foundation, the skeleton of the meaning of every outside sign. (op. cit., p. 29)

Bakhtin distinguishes between two philosophies of language: "Abstract Objectivism" and "Individualist Subjectivism." One of the fundamental positions of the former is that the linguistic system constitutes an external and objective fact beyond the individual consciousness and non-dependent on it. On the other hand, the individualist subjectivism, related to romanticism, places the origin of language in the consciousness of the individual. For Bakhtin, both positions are equivocal; the philosophy of language is the philosophy of ideological signs and vice-versa. In this sense, our consciousness of the world is intermediated by language which not only constitutes a link but also works as a component in the construction of this consciousness.

\footnotetext{
1 "Linguistic turn" refers to current methodologies in social studies that take the language as its center. For Popkewitz, "the linguistic turn centres on the opacity and figurative character of language, the manner in which subject positions as well as reality-effects are created within language" (2001: 50). The term "linguistic turn" was introduced by Rorty in the reader he edited in 1967, The Linguistic Turn, and this marked an ongoing break within analytic thought, moving from the object of language to language itself. For further details, see Rorty 1967; Popkewitz 1997a, b, among others.
} 
To summarize, if we talk about progress in education, we talk about discourses, in other words, a dynamic bundle of power-knowledge interactions that take part in the understanding of the subject (the "self") and objects (things in the world).

\subsubsection{Subject and Object: Discursive Construction}

Each discursive formation has some objects, which vary historically, that we understand as the ordering of the world, that is, the "data." We define data as a collection of objects that have their place and their rule of creation inside each discursive formation. For Foucault:

(...) it is not enough for us to open our eyes, for new objects suddenly to light up and emerge out of the ground. (...) the object does not await in limbo the order that will free it and enable it to become embodied in a visible and prolix objectivity, it does not pre-exist itself, held back by some obstacle at the first edges of light. It exists under the positive conditions of a complex group of relations. (Foucault 1972: 45)

These relations are not inside the objects, they do not pre-exist; they are, somehow, within the limits of discourse, which offers the objects that can be talked about. It is not possible, therefore, to talk about everything in a discursive formation, but only about those things that are allowed for by the rules of object formation. For example, the discourse of Liberalism embodied in every social change, as a pursuit of the objects of truth, talks about the principles of ordering of what is understood as problem and how we classify the society. When one discursive formation classifies some objects as progressive and denies others, it is managing issues of power in order to classify the knowledge. Thus, objects related to the concept of progress should be understood within the rules of a discursive formation. What one discursive formation understands as progress is not the same for another. That is what Kuhn (1970) calls incommensurability among paradigms. Kuhn (op. cit.) provides a view of progress that should be understood inside the same paradigm: what is progress for one paradigm is not for another. He defines progress not cumulatively, but within rules that are historically and socially delimited. His work raises profound questions about the common image of progress, specially related to science as a process of cumulative evolution. For him, "we may, to be more precise, have to relinquish the notion, explicit or implicit, that changes of paradigm carry scientists and those who learn from them closer and closer to the truth" (op. cit., p. 170).

For Kuhn, we should understand progress in another way, by learning "to substitute evolution-from-what-we-do-know for evolution-toward-what-we-wish-to-know [this way], a number of vexing problems may vanish in the process" (op. cit., p. 171).

However, Kuhn does not go further, his conception of progress is positive and idealistic, and he does not de-construct the subject and object and still presupposes an agent.

The notion of agency is relevant to our work. The discourse of progress presupposes a subject of consciousness (an agent) who is the owner of his actions, capable 
of deliberately reaching his aims and transforming the world. On the other hand, as we question his intentionality, relating it to the historical context and, therefore, not to the origin of his actions, we are questioning and de-constructing this basis.

In brief, this chapter argues that the subject is decentered, a conception that is stated by Pêcheux and Fuchs (1975) and Pêcheux (1988) when they talk about the two illusions in which the subject and meaning are inscribed: the first is the illusion of the origin of discourse and the second is the illusion of only one meaning. We adopt a notion in which the subject is decentered, historical, and affected by ideology; incapable of "consciously" transforming the world, he can provoke changes, but does not have control over the meanings of these changes.

\subsubsection{Power and Governmentality}

If we look at the issue of progress through Foucault's lenses, we would challenge the social sciences, interrogating the conditions upon which modern society is constructed and constituted by power relations. For Foucault, power is produced by and produces discursive practices. If we think about schooling as a discursive practice, we have to recognize the power embodied in its relations.

Foucault's studies try to analyze the mechanics of power, how it works in daily struggles, or what he calls the "micro-physics" of power. Before Foucault, the studies about power were interested in detecting and denouncing the other, the opponent: capitalism or socialism, for example, but these studies did not analyze the functioning of power.

On the other hand, from the post-modern point of view, power is not only concentrated in the upper classes, the dominant ones. It penetrates the whole society, constituting itself as a diffuse bundle of micro-powers in the discourses of daily life.

The author offers us three significant hypotheses about power: the first is that power does not exist as an a priori element, it is only conceived in practices or relations; the second is that power does not only work repressively but is also productive, it produces knowledge which produces more power; and the third is that power does not apply only to macro-relations, but also (and mainly) to micro-relations. For the author, "there are no relations of power without resistances" (Foucault 1980: 142). In this sense, Foucault's strategy for studying power does not relate to the subject but to its historicization. He describes this way of studying as genealogy:

(...) a form of history which can account for the constitution of knowledges, discourses, domains of object, etc., without making reference to a subject which is either transcendental in relation to the field of events or runs its empty sameness throughout the course of history. (op. cit., p. 117)

This decentering of the subject enables us to problematize the reason upon which the notion of progress is constructed. From a genealogical point of view, we can see possibilities of change, which could be understood as "breaks, or "movements" in the discursive field. Differently from the traditional history, which constructs prog- 
ress as a linear movement toward the truth, we now have genealogy, which conceives changes as breaks within particular discourses and as power/knowledge struggles. If we transport this idea to schooling, we should study the social and conceptual conditions through which we have come to reason about schooling progress the way we do.

Most of the research that focus on the progress in educational curricula assume that progress is an a priori notion and that students and teachers are stable categories. Taking into account the picture above, critical studies detect a problem, which is avoiding to walk in the direction of an ideal school, analyze this problem within given categories, and finally try to interfere suggesting a possible solution. But, on the contrary, we argue that the notion of progress and the categories of teacher and student are social constructs, and they work as discursive practices in constructing the "self."

Related to Foucault's notion of power, we can quote what he calls "governmentality," which interests us in this study. For the author, it can be understood as:

The ensemble formed by the institutions, procedures, analyses and reflections, the calculations and tactics that allow the exercise of this very specific albeit complex form of power, which has as its target population, as its principal form of knowledge political economy, and as its essential technical means apparatuses of security. (Foucault, in: Burchell, Gordon and Miller (eds), 1991, pp. 102-103)

In Modernity, there was a change in the art of governing, from the sovereignty that governed a territory to a government model focused on population. We can consider governmentality as a diversity of government practices that have the population as the target and the knowledge of economy as action strategy.

The notion of progress in political education discourse can be inscribed as a form of governmentality in the way that the target is the population and the curricula are the apparatuses of security.

After showing the paradigm in which we stand, the following section is dedicated to describe the methodology, that is, the conditions of production of the corpus and take into account the French Discourse Analysis as an analytical tool.

\subsection{Methodology and Conditions of Production}

The data of this research is constituted by curricula documents published between 1980 and 1990, in the state of São Paulo, Brazil.

Discourse analysis methodology requires the examination of the social historical context within which the discourse is constructed followed by a micro-analysis of the texts. The description of the social-historical context, also understood as "conditions of production," aims putting the social representations of the curricular documents, in this case, into focus, as well as the place occupied by the subjects in this discourse. After contextualizing the production of a certain discourse, the analyst concentrates on the properties of the discourse. Discourse is characterized as 
possessing constitutive heterogeneity, which implies that doing discourse analysis is fundamentally trying to find the interdiscourses that are at the interior of a certain discourse. Any discourse is taken as an event inside some discursive formation, or in Pêcheux's words:

(...) any given discourse is the potential sign of a movement within the social historical filiations of identification, inasmuch as it constitutes, at the same time, a result of these filiations and the work (...) of displacement within their space. (Pêcheux 1988: 648)

The conditions of production of our corpus, the curricula documents, involve the social historical moment related to the late 1970s, 1980s, and 1990s, both in the state of São Paulo and the world.

Globally, we had a process of globalization with a consequent domination by the industrialized countries, mainly the United States, during the last decades of the twentieth century. This process resulted in a scientific, technological, cultural, and linguistic domination by the first world countries in relation to the emergent ones, like Brazil. This installed a sentiment of excluded country that will be felt in education.

In Brazil, at the end of the 1970s and beginning of the 1980s, we could see a process of political opening after the falling of the dictatorship that operated with the raising of many political parties and a feeling of democratization of Education. The great problem of this period was that at the same time new schools were being opened, the quality of education was falling, especially the public ones as the quality is directed to the elite that attend private schools.

In the political sphere of the state of São Paulo, in 1982 the Governor Franco Montoro, from the PMDB (Partido do Movimento Democrático Brasileiro, Party of the Brazilian Democratic Movement), was elected. The workers in education expected democratic improvements from the new governor, taking into account his democratic political discourse. His motto was "Caminhando para o fim do quadronegro," that is, "Walking to the end of the blackboard," or alternatively, "walking to the end of a bad situation." It is important to call the reader's attention to two possible meanings for "quadro-negro" in Portuguese. It is a compound word, and the first word "quadro" can also be understood as "picture" or in a metaphorical sense as "situation" or "context." This way, "quadro negro" can relate to both the blackboard where teachers usually write during their classes and the terrible situation in which Montoro found education when elected, which he implies is "negro" (black). We can say that the interlocutor was using this double sense as a strategy of persuasion, in this case, of political change in education. This discursive strategy of using a word that belonged to both discursive formations, that of the school and that of the social situations, caught the readers' attention, in this case the teachers, to point out the terrible conditions of the schools. Of course he, the governor, would come to the rescue.

It is within this feeling of change that the curricula documents appeared from which we chose excerpts to analyze. 


\subsection{Micro-Analysis}

For the Discourse Analysis, we analyze excerpts of the discourse, the microanalysis, in a way to identify the effects of meanings and point to the linguistic materiality. These excerpts are considered inside the conditions of production, that is, the social-historical moment in which they appear. In our case, as specified in part 2, the moment is of change, in politics and education.

If we take, for example, the discourse of curricula reforms in Brazil, we will see that it is constructed upon dichotomies: the old and the new. The "old" is seen as the bad, the evil, the one that failed, and the "new" is associated with the modern, the complete, in short, "hope." Reforms are always initiated by the government, they are top-down reforms and the discourse of reforms is embodied in the Political Discourse.

Political Discourse works in the way of political engagement: the speaker (X) intends to engage the listener (Y) in a political ideology (Z). For example, curricula reforms, in Brazil, frequently happen when the government changes, as a way of establishing a mark, a feature, and a style of governance. Political issues mean action and action in education means curricula change, among other changes.

One of the characteristics of the Political Discourse of reforms in Brazil is the use of metaphors. These metaphors are constructed upon dichotomies. Education as a "process" is one example of metaphor. Below, we present some parts of two introductory letters that appear in a Curriculum signed by two secretaries of Education of São Paulo state.

The curricula proposals that are being delivered now to the teams of public schools are the product of a long process of construction that has been forged into successive versions by the decisive collaboration of countless educators.

By debating, disagreeing and sending suggestions, specialists from different regions of São Paulo state, in different moments, provided the technical team of the Coordenadoria de Estudos e Normas Pedagógicas—CENP—-the backgrounds needed for the modification and improvement of this set of guiding teaching documents.

Therefore, it is a proposal that has been collectively built, but has not been finished. (Modern Language Curricula Proposal, 1988) ${ }^{2}$ (...)

The public school should distance itself from the current model (...) It should transform itself into a living and active organism and part of the life of the society. (Modern Language Curricula Proposal, 1992) ${ }^{3}$

\footnotetext{
${ }^{2}$ My translation of part of a letter addressed to the teachers.

As propostas curriculares que estão sendo entregues, neste momento, às equipes da rede estadual de ensino são produto de um longo processo de construção que foi se forjando, em sucessivas versões, através da colaboração decisiva de inúmeros educadores. Debatendo, discordando e encaminhando sugestões, professores especialistas, das mais diferentes regiões do Estado de São Paulo, em diferentes momentos, forneceram às equipes técnicas da Coordenadoria de Estudos e Normas Pedagógicas-CENP—os subsídios necessários à modificação e aprimoramento deste conjunto de documentos norteadores do trabalho docente. Trata-se, portanto, de uma proposta coletivamente construída, mas não acabada. (...) (carta do Secretário da Educação Chopin Tavares de Lima - P.C. $1^{\circ}$ g., 1988)
}

${ }^{3} \mathrm{My}$ translation of part of a letter addressed to the teachers.

A escola pública deve se afastar do modelo atual (...). Ela deve se transformar em organismo 
In these two examples, the metaphor of education reforms as a "process" is constructed along two axes: a) a spatial and b) a temporal one. In space, education is seen as a "building," and the reform is one step forward in its construction. We can visualize the spatial image of constructing the building step-by-step toward an ideal in the use of the words: construction, process, forge, successive versions, collaboration, and collectively built. It seems that everyone could go there and add a brick in order to raise that building. The other axis is the temporal one. We can see that there is a "before time" (the current model that should be changed) and an "after time" (alive and active organism) related to the curricula reform. The images associated with the previous time are always of incompleteness, as it is advised that the new model should distance itself from the current model, that is, the school is supposed to change, in time. ${ }^{4}$ On the other hand, the images related to the time that comes after the reform are visualized as a social progress: alive and active organism in the society.

Another characteristic is that the curricula reform is addressed to teachers and other people in education who are not supposed to be familiar with the new educational concepts. This kind of discourse aims to facilitate the philosophical trends of the reform to the addressee.

As part of this image of construction, another step is presented in the curriculum discourse: its dissemination to the teachers and their subsequent training. We can see here an ideological point of view: the teacher is seen as unprepared and unable to understand, so he/she is in need of training; the role of the government is to empower the teacher. This ideology is based on the illusion that both share the same ideas and justifies, at the same time, the government power. Example:

Now begins a new step in the work: training the educators in the new curricula as part of the educational politics of the Education Secretary, with the aim of the re-qualification of Fundamental Public School. (Modern Language Curricula Proposal, 1988)

One of the columns of this building is the rescue of quality in public school. Notable in this excerpt is the desire to "pursue the lost quality," an argument that consists of not completely denying a certain quality in the previous education system (this is supposed to be politically incorrect), and instead using the prefix "-re" added to the deverbal noun "qualification" to simultaneously imply two different meanings: that it is necessary to change-by constructing some columns in this building - and that, even though in the past the quality was not desirable, it was not

vivo e atuante na vida da sociedade (...) (carta do Secretário da Educação Fernando Moraes - P.C., $1^{\circ}$ g. 1992).

4 "Current" understood as the old one, considered, in opposition to the new one, as "dead" (nonalive) and "stuck" (non-active).

${ }^{5} \mathrm{My}$ translation of part of a letter addressed to the teachers.

Agora inicia-se uma nova etapa de trabalho: a da divulgação das Propostas e capacitação dos educadores, dentro de uma política educacional da S. E., com vistas à requalificação da escola pública de Primeiro Grau. (carta do Secretário da Educação Chopin Tavares de Lima - P.C. $1^{\circ}$ g., 1988). 
always bad. It is necessary to reinforce the foundations and give continuity to the process of construction.

The image of progress, as conceived through the metaphor of construction, is based on a linear and cumulative action toward an ideal of completeness. This concept of completeness can only be understood in opposition to incompleteness, in our context applied to the previous curriculum documents. This is what Derrida calls "the play of differences" (Derrida 1968: 140) in which our western rationality is inscribed. When exalting the new, this discourse shows traces of inadequacy and failure in relation to the old. The positive meaning regarding the curricula reforms is constructed with the voice of negative failure implied by the previous curricula, and in this discursive game, the two meanings end entwined: the new inscribes in the sphere of the old and one depends on the other to signify.

In the line stream of thinking, the excerpt below is based upon dichotomies. For example, in favor of a change in the linguistic approach, the curriculum proposal quotes the following extract from a book published in English by G. Brown:

\begin{abstract}
Are all classes dead? No, not all. But too damned many are... What's the difference between a dead and a live classroom? In the dead classroom, learning is mechanistic, routine, over ritualized, dull and boring. The teacher is robotized and the children are conceived as containers or receptacles whose primary function is to receive and hold subject matter... The live classroom... is full of learning activities in which students are enthusiastically and authentically involved... Each student is genuinely respected and treated as a human being by his teacher... the learning involves living. (Brown 1975: 1-2, cited in Pedagogical Practice, 1993: 22) ${ }^{6}$
\end{abstract}

The explicit dichotomies upon which the argument is constructed are the images of death and life. The image of death is related to the previous (or old) approach and the image of life (alive) is associated with the new one. Reform means the passage from death to life. In order to create the illusion of death, the author uses the following adjectives and nouns: mechanistic, routine, ritualized, dull, boring, robotized, containers, and receptacles. The image of life is created by the phrases: enthusiastically and authentically involved, genuinely respected, and treated as human being. This image of passage from death to life has its origin in the religious discourse, especially the one related to Catholicism, the most common religion in Brazil.

We could point to other images of incompleteness related to curriculum reforms: the image of the teacher as a person not prepared to understand the curricula or to work with the syllabus and to deal with the student. The image of the student as an empty individual who needs to be constructed, who has no past and no history. The notion of student is considered in a homogeneous way, because there is no space in the educational discourse for heterogeneity. The image of teaching is seen as an act of using strategies and the image of learning is to incorporate behaviors (Pennycook 1994).

\footnotetext{
${ }^{6}$ From: Brown, G. I. The live classroom. New York: The Press Viking, 1975: 1-2. It has been quoted inside "Pedagogical Practice" according to the original, in English. In: SÂO PAULO (Estado) Secretaria da Educação. CENP. Língua Estrangeira Moderna-Inglês: $1^{\circ}$ grau. São Paulo: SE/CENP, 1993. v. 1 (Prática Pedagógica). P. 22.
} 
But what does this discourse of incompleteness imply? It implies that there is a silent referent of completeness, as it was said by Chakrabarty (1992: 337) when referring to the first world, upon which the discourse of incompleteness is constructed. This desire of completeness generates reforms in education based upon an a priori concept of progress toward an ideal school. The concept of Liberalism presupposes a centered subject that is able to transform this world consciously, and reforms in education are seen as the march of progress.

According to Popkewitz (2013), "modern pedagogy is a major example of producing human kinds in the new republics" and progress is inscribed in modern pedagogy as fabricating "the kind of person who orders and calculates the paths of the present to the future in organizing biography will bring individual and social happiness and progress" (Popkewitz 2013: 136).

\subsection{Final Remarks}

We started this research with the hypothesis that the curricula reform discourse is constructed based on the ideal of completeness that characterizes the Liberalist philosophy in the search of progress, freedom, truth, and social wealth, characteristics inscribed in the notion of Foucault's governmentality. However, this same discourse excludes even as it includes the more discourses are created to promote the inclusion in Education, the more it seems to appear the excluded subjects in Education (Kontopodis 2012).

Our point here was not to argue what does or doesn't work in curriculum reforms related to pedagogical practices. By using Foucault's belief (Foucault 1980) that knowledge is power, we wanted to show that power is embodied in the discourses we produce about ourselves, which intervene in social affairs. The curriculum discourse, seen as discursive practices of schooling, does not only transmit ideas or produce instrumental pedagogy, it creates principles of reality by comparing, differentiating, hierarchizing, and dividing the subjectivities of the teachers and the students. Our approach was to examine how the discourse functions, especially the power-knowledge relations, inscribed in the notion of governmentality, responsible for the reasoning of Brazilian schooling.

The main effect of meaning in the data analyzed was the conception of this document as a construction, that is, with many educational subjects (governors, teachers and others) democratically involved. This is also the main argument of the curriculum reform discourse, based on the images of the Liberalist philosophy of our current time, as we have seen in the conditions of production of the discourse. However, the analysis examined the discourse in light of the social historical context. Within this, the analysis tried to deconstruct some naturalized images and see the discourse as a historical construction, in this case related to education.

In relation to this, we quote Foucault's ideas about the systems in which we are prisoners: 
My problem is essentially the definition of the implicit systems in which we find ourselves prisoners; what I would like to grasp is the system of limits and exclusion which we practice without knowing it; I would like to make the cultural unconscious apparent. (Foucault, Rituals of Exclusion, cited in Butler 1997: 83)

Any progressist point-of-view of Education is based on a liberalist concept of universal freedom in the world. But, behind this idea of universality, in its local application, as we have pointed in the examples above, Liberalism shows another face: it sustains politically exclusionary practices. These are the effects of Liberalism: inclusion in a universal view and exclusion in a local one (Mehta 1997). This happens because the concept of Liberalism is taken as transhistorical, transcultural, and transracial, but in practice, relations among people are crossed by power.

In Foucault's words, we would say that "schooling systems," conceived from the principles of Liberalism, are systems of prison and exclusion. The above considerations bring us to consider the Brazilian Curricula Discourse as an example of local exclusion. We conclude that the discourse of incompleteness in the Brazilian example works against itself; when it affirms the other, it really denigrates itself, naturalizing the dichotomies upon which the discourse is constructed. This is what Bourdieu (1991: 146) calls "the return of the repressed."

This search of completeness, which feeds the discourse of progress, can be understood in light of governmentality, as inscribed in the new mode of state regulation which takes into account the individual self-regulation in the search of success and excellence, which was made possible in liberal societies.

But what is the role of research in a discursive paradigm? Not to tell the readers what they have to do or how they have to see, but to raise new and unthinkable questions and make new ones come to the minds of readers. To understand without having to be told, to read between the lines. To look at the evidence, decentering, problematizing, and questioning it. To look at what is familiar and make it strange. To disturb people's mental habits. To reexamine rules and institutions. To see educational reforms as discourses constructed according to certain social historical and ideological rules. To destabilize the reasoning of education. By questioning, not by answering, as the positivist philosophy conceives, is the only way, in my point of view, to open up the possibility of different ways of thinking education and starting a movement of transformation.

\section{References}

Bakhtin, M. (1973). Marxism and philosophy of language. New York: Seminar.

Bourdieu, P. (1991). Language \& symbolic power. Cambridge, MA: Harvard University Press.

Brown, G. I. (1975). The live classroom. New York: The Press Viking.

Butler, J. (1997). The psychic of life power. Theories in subjection. Stanford, CA: Stanford Press.

Chakrabarty, D. (1992). Provincializing Europe: Post coloniality and the critique of history. Cultural Studies, 6(3), 337-357.

Derrida, J. (1968). Différance. In J. Derrida (Ed.), Speech and phenomena. Evanston, IL: Northwestern University. 
Foucault, M. (1972). The archaeology of knowledge. New York: Harper \& Row.

Foucault, M. (1980). Power/Knowledge: Selected Interviews and other writings. (trans. and ed. Colin Gordon). New York: Pantheon.

Foucault, M. (1991). 'Governmentality', trans. Rosi Braidotti and revised by Colin Gordon. In G. Burchell, C. Gordon, \& P. Miller (Eds.), The Foucault effect: Studies in governmentality. Chicago, IL: University of Chicago Press.

Kontopodis, M. (2012). Neoliberalism, pedagogy, and human development: Exploring time, mediation, and collectivity in contemporary schools. New York: Routledge.

Kuhn, T. (1970). The structure of scientific revolutions. Chicago, IL: University of Chicago Press.

Mascia, M. A. A. (2009). Inclusion or exclusion? An analysis of the Brazilian Curriculum Discourse of the 1980s and the 1990s. In M. Kontopodis (Ed.), Culture and emerging educational challenges: A dialogue with Brazil/Latin America. Berlin: Lehmanns Media.

Mehta, U. S. (1997). Liberal strategies of exclusion. In F. Cooper \& A. L. Stoler (Eds.), Tensions of empire. Berkeley, CA: University of California Press.

Pêcheux, M. (1988). Discourse: Structure or event? In C. Nelson \& L. Grossberg (Eds.), Marxism and the interpretation of culture (pp. 633-650). Urbana, IL: University of Illinois Press.

Pêcheux, M., \& Fuchs, C. (1975). Mises au point et perspectives à propos de l'analyse automatique du discours. In Langages (p. 37). Didier-Larouse: Paris.

Pennycook, A. (1994). The cultural politics of English as an International Language. New York: Longman.

Popkewitz, T. S. (1997a). Restructuring of social and political theory in education: Foucault and a social epistemology of school practices. Educational Theory, 47(3), 287-313.

Popkewitz, T. S. (1997b). The production of reason and power: Curriculum history and intelectual traditions. J. C. Curriculum Studies, 29(2), 131-164.

Popkewitz, T. S. (2013). The impracticality of practical knowledge and lived experience in educational research. Nordic Studies in Education, 33, 124-139.

Popkewitz, T. S., Franklin Barry, M., \& Pereira, M. A. (Eds.). (2001). Cultural history and education. New York: Routledge \& Falmer.

Rorty, R. (1967). The lingusitic turn: Essays in philosophical method. Chicago, IL: The University of Chicago Press.

Usher, R., \& Edwards, R. (1994). Postmodernism and education. New York: Routledge.

Márcia Aparecida Amador Mascia is a professor at the Graduate Program in Education at "Universidade São Francisco" in the state of São Paulo, Brazil. She is the leader of the Brazilian research group "Estudos Foucaultianos e Educação" (Foucaultian Studies and Education), certified by CNPq. She worked as the coordinator of the Graduate Program for 2 years (2012-2013) and has acted as member of many committees. Her approach is based on French Discourse Analysis, Foucault's archeological and genealogical studies, deconstruction, and psychoanalysis within the broader post-modern social theory. Her research interests are the discourses and the identities in education, especially on curriculum, teachers' education, the teaching and learning of languages, the conflict of oral languages and sign languages for deaf students, the discourses of exclusion and resistance of education and, more recently, the external assessments, like PISA. 
Open Access This chapter is licensed under the terms of the Creative Commons Attribution 4.0 International License (http://creativecommons.org/licenses/by/4.0/), which permits use, sharing, adaptation, distribution and reproduction in any medium or format, as long as you give appropriate credit to the original author(s) and the source, provide a link to the Creative Commons licence and indicate if changes were made.

The images or other third party material in this chapter are included in the chapter's Creative Commons licence, unless indicated otherwise in a credit line to the material. If material is not included in the chapter's Creative Commons licence and your intended use is not permitted by statutory regulation or exceeds the permitted use, you will need to obtain permission directly from the copyright holder. 